\title{
REFERENCES
}

Ammundsen, E. (1941). J. biol. Chem. 138, 563.

Brooks, J. (1935). Proc. Roy. Soc. B, 118, 560.

Campbell, D. \& Morgan, T. N. (1939). Lancet, 2, 123.

Conant, J. B. \& Fieser, L. F. (1924-5). J. biol. Chem. 62, 623.

Conant, J. B., Scott, N. D. \& Douglass, W. F. (1928). J. biol. Chem. 76, 223.

Cox, W. W. \& Wendel, W. B. (1942). J. biol. Chem. 143, 331.

Drabkin, D. L. \& Schmidt, C. F. (1945). J. biol. Chem. 157, 69.

Gilligan, D. B., Altschule, M. D. \& Katersky, E. M. (1943). J. clin. Invest. $22,859$.

Hartridge, H. \& Roughton, F. J. W. (1927). J. Physiol. 62, 232.

Havemann, R., Jung, F. \& Issekutz, B. v. (1939). Biochem. Z. $301,116$.
Jope, H. M., Jope, E. M. \& O'Brien, J. R. P. (1943). Biochem. J. 37, ix.

Kallner, S. (1945). J. Physiol. 104, 6.

Mathison, G. C. (1911). J. Physiol. 43, 347.

Paul, W. D. \& Kemp, C. R. (1944). Proc. Soc. exp. Biol., N.Y., 56, 55.

Prunty, F. T. G. \& Vass, C. C. N. (1943). Biochem. J. 37, 506.

Ramsay, W. N. M. (1944a). Biochem. J. 38, 467.

Ramsay, W. N. M. (1944b). Biochem. J. 38, 470.

Roughton, F. J. W., Darling, R. C. \& Root, W. S. (1944). Amer. J. Physiol. 142, 708.

Sendroy, J., jr., Dillon, R. T. \& Van Slyke, D. D. (1934). J. biol. Chem. 105, 897.

Van Slyke, D. D. \& Hiller, A. (1928). J. biol. Chem. 78, 807.

Wendel, W. B. (1938). J. lab. clin. Med. 24, 96.

Woodward, G. E. \& Fry, E. G. (1932). J.biol. Chem. 97, 465.

\section{The Component Acids of Cow Colostrum Fat}

\author{
By C. P. ANANTAKRISHNAN, V. R. BHALE RAO AND T. M. PAUL, \\ Imperial Dairy Research Institute, Bongalore
}

(Received 14 January 1946)

Though much work has been done on the composition of milk fat, little attention has so far been paid to the fat secreted during the first few days after parturition. Baldwin \& Longenecker (1944a) studied the fatty acid distribution in the fat of human milk during the first few days of lactation and found that it was different from that of mature milk fat. The results of these workers indicated that as the period of lactation progressed from the first day's colostrum to mature milk, the amount of the acids of greater molecular weight than $\mathrm{C}_{18}$ decreased and the amount of $\mathrm{C}_{12}$ and $\mathrm{C}_{14}$ acids increased. Later, Baldwin \& Longenecker (1944b) investigated the colostrum fat of a single cow collected during the first 4 days after parturition and reported that its fatty acid composition was very similar to that of a typical butter fat. The results obtained were only from samples collected from a cow of unspecified breed and comparisons were made with the results of the analysis of typical butter fat by Hilditch \& Longenecker (1938). It is possible that if a sample of butter fat from the same cow had been collected and analyzed at a later period some differences might have been observed. Apart from these investigations no work appears to have been carried out on this subject. In the present study attèmpts were made to collect colostrum fat from some of the common breeds of cattle in India and the results obtained are now presented.

\section{METHODS}

The colostrum from which the fat was extracted for the present studies was collected from four different breeds of cows, namely, Sindhi, Gir, Tharparkar and Sahiwal. Milking was done twice a day. In the case of each animal material collected during each $24 \mathrm{hr}$. after parturition was mixed together, diluted with water and the cream separated. Butter fat was prepared direct from the cream by the 'boiling off' method. The butter fat prepared from each $24 \mathrm{hr}$. collection from every animal was first analyzed for its general chemical characteristics. The collection of butter fat was continued during the first 15 days of lactation and samples from the first: 5 days and the tenth day of lactation were used in the present studies.

During the dry period the cows were receiving $3 \mathrm{lb}$. of a concentrate mixture (wheat bran, ground-nut cake, grain husk and grain in the ratio of $4: 2 \cdot 5: 2 \cdot 0: 1 \cdot 5$ ) in addition to $\frac{1}{2} \mathrm{lb}$. each of extra grain husk and ground-nut cake. Four weeks before calving pregnant animals were fed $3 \mathrm{lb}$. of the usual concentrate mixture mentioned above with $3 \mathrm{lb}$. of wheat bran. For the first 4 days after calving the animals received $8 \mathrm{lb}$. wheat bran, $1 \mathrm{lb}$. of jaggery (crude cane sugar), with a roughage consisting of $55 \mathrm{lb}$. green grass and $3 \mathrm{lb}$. ragi straw. From the fifth day of lactation onwards the animals were fed, together with the usual amount of roughage as mentioned above, different amounts of the common concentrate mixture according to milk yield.

Representative composite mixtures of the colostrum fat during the initial days of lactation were obtained by mixing equal quantities of the fat collected from the different cows 
on the corresponding days of lactation. This mixed butter fat for each day of lactation was first analyzed for its physical and chemical characteristics and then subjected to detailed analysis by ester fractionation according to the method of Hilditch, as modified by Smith \& Dastur (1938). The fat was converted into methyl esters directly and then the lower components fractionally separated from the whole bulk, the higher members being separated into liquid and solid acids by Twitchell's lead salt method, methylated and also fractionally distilled. The detailed results obtained for the composition of the three main fractions, the lower, solid and liquid esters of the colostrum fat on the first day are given by way of illustration in Tables 2 and 3, while the final figures are recorded in Table 4. Unfortunately the small amounts of material available for analysis prevented isolation of the lower unsaturated acids $\mathrm{C}_{10}, \mathrm{C}_{12}$ and $\mathrm{C}_{14}$ in the present work. Their existence in butter fat has, however, been established beyond doubt by Bosworth \& Brown (1933), Hilditch \& Paul (1936) and other workers.

\section{RESULTS}

The chemical characteristics of the individual samples of colostrum fat and those of composite mixtures are shown in Tables 1 and $1 a$. Table 1 shows clearly that as time goes on there is a marked progressive change in the nature of the fat secreted by individual animals as judged by the butyrorefractometer reading, and the iodine, saponification and Reichert values. These changes were very similar for all the animals except cow 531, in which the transition was not so well marked. In every case the butyro-refractometer reading decreased from $45 \cdot 4$ to about $42 \cdot 1$ during the progress of lactation. The saponification value gradually increased from about 213 to 232 . The Reichert value rapidly increased from about 13 on the first day to 20 on the second day and then gradually increased to about 30. The iodine value decreased from about 40 to 32 . The results of analyses of the composite mixtures also reveal the same gradation in all their chemical constants (Table $1 a$ ). The most interesting observation concerns, perhaps, the physical state of the colostrum samples; the melting-point of the fat gradually decreases with the progress of lactation. This may be attributed to the presence of larger amounts of stearic acid in the colostrum fat relative to the normal butter fat collected later.

The decrease in the butyro-refractometer reading and iodine value, and an increase in the saponification and Reichert values of the fat secreted by the animal as the colostrum fat changed to normal butter fat suggested a marked increase in the amount of fatty acids of low molecular weight and a slight decrease in the content of unsaturated acids. This was confirmed by detailed analysis based on fractional distillation methods. Tables 2 and 3 giving the detailed analytical results for fat in the first day of lactation, illustrate the methods. Table4, wherein the component fatty acids for all the samples by weight and molar percentages are presented in summarized form, shows clearly that there is a regular increase in the proportion of the low molecular weight fatty acids during the transition from the first day's colostrum fat to mature milk fat on the tenth day of lactation. The butyric acid content increased from $2 \cdot 2$ to $3.6 \%$. The amount of caproic acid in the fat was almost negligible on the first day. It gradually increased up to $1.5 \%$ on the fourth day and then decreased to $0.6 \%$, at which level it remained constant. Caprylic, capric and lauric acids also increased till the fourth day after parturition and remained fairly steady. There appeared to be little change in the proportion of myristic acid, the slight increase in its content being counterbalanced by a slight decrease in stearic acid. The palmitic acid content of the secreted fat slightly increased on the second day after calving and then became constant. The amount of arachidic acid remained almost constant. The changes in the lower acids can be seen more clearly by reference to molar percentages. There is an increase of about $10 \mathrm{~mol} . \%$ in the lower acids up to and including $\mathrm{C}_{14}$. This is mainly accounted for by the fall of almost $6 \mathrm{~mol} . \%$ in oleic acid. The fall in the percentage of stearic acid is also evident. In the unsaturated acids up to $\mathrm{C}_{14}$ there is virtually no change. The amount of hexadecenoic acid increased at first and then decreased to almost the original value. The chief change appeared to be in oleic acid, which decreased from $34 \cdot 1$ on the first day to 27.5 on the fourth day and then slightly increased to $\mathbf{2 9 . 3}$ on the tenth day of lactation. The amount of linoleic acid decreased gradually to almost one-quarter of its amount present in the first day's fat. There was no marked change in the $\mathrm{C}_{20-22}$ unsaturated acids. These changes, a decrease in the quantity of higher acid and an increase in the amount of lower acids, may well be associated with the functional development of the lactating mammary gland following parturition. A gradual decrease in the percentage of oleic acid and low amounts of volatile acids present in the colostrum fat are in close agreement with the findings that colostrum fat is richer in oleic acid and contains less volatile fatty acids than normal milk fat (Sommerfeld, 1909; Nilson, 1891). In comparison with the component fatty acids of human colostrum fat (Baldwin \& Longenecker, 1944a) several differences in composition are apparent. The most interesting observation is the presence of larger amounts of low molecular weight fatty acids and smaller amounts of $\mathrm{C}_{20}$ and $\mathrm{C}_{22}$ acids in cow colostrum fat than in human colostrum fat. The first day's cow colostrum fat compares favourably with the mature human milk fat, the percentage of lower acids up to $\mathrm{C}_{14}$ being almost the same (16.4 and 17.8 respectively). The only point of 
Table 1. General analytical characteristics of colostrum and milk fats

\begin{tabular}{|c|c|c|c|c|c|c|}
\hline $\begin{array}{l}\text { Day of } \\
\text { lactation }\end{array}$ & $\begin{array}{l}\text { Butyro-re- } \\
\text { fractometer } \\
\text { reading } \\
\left.\text { (at } 40^{\circ}\right)\end{array}$ & $\begin{array}{l}\text { Saponification } \\
\text { value }\end{array}$ & $\begin{array}{l}\text { Iodine } \\
\text { value }\end{array}$ & $\begin{array}{l}\text { Reichert } \\
\text { value }\end{array}$ & $\begin{array}{c}\text { Polenske } \\
\text { value }\end{array}$ & $\begin{array}{l}\text { Kirschner } \\
\text { value }\end{array}$ \\
\hline \multicolumn{7}{|c|}{ Cow 82. Gir (2nd lactation) } \\
\hline 1 & $45 \cdot 2$ & $213 \cdot 7$ & $38 \cdot 60$ & $13 \cdot 16$ & 0.95 & $12 \cdot 31$ \\
\hline 2 & $44 \cdot 2$ & $220 \cdot 4$ & $\mathbf{3 5} \cdot 20$ & $18 \cdot 99$ & $1 \cdot 40$ & $17 \cdot 31$ \\
\hline 3 & $43 \cdot 0$ & $224 \cdot 2$ & $33 \cdot 40$ & $22 \cdot 22$ & $1 \cdot 61$ & $20 \cdot 75$ \\
\hline 4 & $42 \cdot 1$ & $224 \cdot 8$ & $29 \cdot 70$ & $23 \cdot 39$ & $2 \cdot 20$ & $21 \cdot 62$ \\
\hline 5 & $41 \cdot 6$ & $226 \cdot 2$ & $30 \cdot 00$ & $29 \cdot 21$ & $2 \cdot 30$ & $25 \cdot 86$ \\
\hline 10 & $41 \cdot 0$ & $228 \cdot 2$ & $29 \cdot 45$ & $32 \cdot 82$ & $1: 27$ & $30 \cdot 54$ \\
\hline 15 & $41 \cdot 0$ & $229 \cdot 3$ & $33 \cdot 95$ & $30 \cdot 71$ & 1.99 & $29 \cdot 17$ \\
\hline \multicolumn{7}{|c|}{ Cow 251. Sindhi (11th lactation) } \\
\hline 1 & $45 \cdot 3$ & $215 \cdot 4$ & $\mathbf{3 8 \cdot 3 0}$ & $14 \cdot 75$ & $1 \cdot 10$ & $12 \cdot 02$ \\
\hline 2 & $44 \cdot 0$ & $223 \cdot 0$ & $\mathbf{3 5 \cdot 3 0}$ & $21 \cdot 32$ & $1 \cdot 25$ & $19 \cdot 87$ \\
\hline 3 & $42 \cdot 9$ & $224 \cdot 4$ & $32 \cdot 80$ & $24 \cdot 35$ & 1.40 & $22 \cdot 80$ \\
\hline 4 & $41 \cdot 3$ & $226 \cdot 0$ & $31 \cdot 00$ & $\mathbf{3 0} \cdot \mathbf{2 3}$ & $1 \cdot 25$ & $26 \cdot 81$ \\
\hline 5 & $42 \cdot 0$ & $231 \cdot 2$ & $30 \cdot 60$ & $\mathbf{3 1} \cdot \mathbf{3 0}$ & $2 \cdot 10$ & $28 \cdot 26$ \\
\hline 10 & $42 \cdot 5$ & $230 \cdot 1$ & $\mathbf{3 4} \cdot 20$ & $31 \cdot 40$ & $2 \cdot 10$ & $27 \cdot 80$ \\
\hline 15 & $42 \cdot 0$ & $231 \cdot 4$ & $32 \cdot 10$ & $31 \cdot 77$ & $1 \cdot 75$ & $27 \cdot 14$ \\
\hline \multicolumn{7}{|c|}{ Cow 257. Tharparkar (4th lactation) } \\
\hline 1 & $45 \cdot 5$ & $213 \cdot 3$ & $41 \cdot 58$ & $13 \cdot 98$ & 0.97 & $12 \cdot 54$ \\
\hline $\mathbf{2}$ & $44 \cdot 0$ & $221 \cdot 9$ & $38 \cdot 68$ & $21 \cdot 45$ & 1.59 & $20 \cdot 07$ \\
\hline$\overline{3}$ & $42 \cdot 8$ & $224 \cdot 8$ & $\mathbf{3 4} \cdot \mathbf{5 3}$ & $\mathbf{2 3} \cdot 28$ & $2 \cdot 30$ & $21 \cdot 78$ \\
\hline 4 & $42 \cdot 2$ & $226 \cdot 0$ & $34 \cdot 71$ & $28 \cdot 64$ & $2 \cdot 20$ & $24 \cdot 91$ \\
\hline 5 & $42 \cdot 2$ & $228 \cdot 6$ & $34 \cdot 84$ & $28 \cdot 76$ & $1 \cdot 89$ & $25 \cdot 11$ \\
\hline 10 & $42 \cdot 7$ & $228 \cdot 2$ & $35 \cdot 72$ & $30 \cdot 79$ & $1 \cdot 69$ & $27 \cdot 10$ \\
\hline 15 & $42 \cdot 8$ & $227 \cdot 4$ & $36 \cdot 83$ & $29 \cdot 67$ & $1 \cdot 79$ & $26 \cdot 21$ \\
\hline \multicolumn{7}{|c|}{ Cow 531. Ayrshire-Hariana (12th lactation) } \\
\hline 1 & $43 \cdot 9$ & $219 \cdot 3$ & 32.98 & $15 \cdot 82$ & $1 \cdot 21$ & $13 \cdot 61$ \\
\hline 2 & $42 \cdot 8$ & $223 \cdot 1$ & $28 \cdot 98$ & $19 \cdot 05$ & $1 \cdot 79$ & $17 \cdot 33$ \\
\hline 3 & $42 \cdot 0$ & $225 \cdot 2$ & $29 \cdot 75$ & $21 \cdot 34$ & $1 \cdot 89$ & $18 \cdot 48$ \\
\hline 4 & $41 \cdot 3$ & $226 \cdot 1$ & $28 \cdot 28$ & $26 \cdot 18$ & $2 \cdot 20$ & $22 \cdot 84$ \\
\hline 5 & $41 \cdot 0$ & $228 \cdot 0$ & $28 \cdot 75$ & $28 \cdot 43$ & $2 \cdot 30$ & $24 \cdot 62$ \\
\hline 10 & $42 \cdot 7$ & $228 \cdot 0$ & $\mathbf{3 0} \cdot 54$ & $27 \cdot 63$ & $2 \cdot 10$ & $23 \cdot 66$ \\
\hline 15 & $41 \cdot 3$ & $229 \cdot 2$ & $29 \cdot 82$ & $29 \cdot 22$ & $2 \cdot 50$ & $25 \cdot 83$ \\
\hline \multicolumn{7}{|c|}{ Cow 64. Sahiwal (3rd lactation) } \\
\hline 1 & $45 \cdot 4$ & $213 \cdot 5$ & $42 \cdot 79$ & $14 \cdot 59$ & $0 \cdot 75$ & $12 \cdot 66$ \\
\hline 2 & $45 \cdot 2$ & $214 \cdot 9$ & $41 \cdot 62$ & $18 \cdot 05$ & $0 \cdot 75$ & $15 \cdot 12$ \\
\hline$\overline{\mathbf{3}}$ & $43 \cdot 9$ & $218 \cdot 0$ & $\mathbf{3 8} \cdot \mathbf{3 9}$ & $19 \cdot 48$ & $1 \cdot 15$ & $16 \cdot 87$ \\
\hline 4 & $43 \cdot 4$ & $221 \cdot 7$ & $36 \cdot 12$ & $21 \cdot 74$ & $1 \cdot 40$ & $19 \cdot 05$ \\
\hline 5 & $42 \cdot 7$ & $226 \cdot 0$ & $\mathbf{3 3} \cdot 48$ & $24 \cdot 27$ & $1 \cdot 70$ & $20 \cdot 77$ \\
\hline 10 & $42 \cdot 1$ & $228 \cdot 0$ & $31 \cdot 32$ & $27 \cdot 07$ & $1 \cdot 70$ & $23 \cdot 93$ \\
\hline 15 & $41 \cdot 6$ & $230 \cdot 0$ & $30 \cdot 84$ & $26 \cdot 41$ & $1 \cdot 30$ & $23 \cdot 30$ \\
\hline \multicolumn{7}{|c|}{ Cow 64. Gir (5th lactation) } \\
\hline $\mathbf{1}$ & $\mathbf{4 4 \cdot 2}$ & $218 \cdot 0$ & $38 \cdot 42$ & 13.98 & $1 \cdot 20$ & 12.92 \\
\hline 2 & $43 \cdot 8$ & $220 \cdot 3$ & $36 \cdot 53$ & $19 \cdot 00$ & 1.59 & $17 \cdot 38$ \\
\hline 3 & $43 \cdot 5$ & $222 \cdot 0$ & $35 \cdot 12$ & $22 \cdot 35$ & $1 \cdot 79$ & $20 \cdot 95$ \\
\hline 4 & $43 \cdot 1$ & $225 \cdot 1$ & $32 \cdot 50$ & 24.95 & 1.99 & $23 \cdot 68$ \\
\hline $\mathbf{5}$ & $42 \cdot 8$ & $227 \cdot 4$ & $31 \cdot 67$ & $26 \cdot 06$ & $1 \cdot 79$ & $22 \cdot 46$ \\
\hline 10 & $42 \cdot 3$ & $229 \cdot 6$ & $32 \cdot 01$ & $32 \cdot 02$ & $1 \cdot 79$ & $29 \cdot 20$ \\
\hline 15 & $42 \cdot 5$ & $228 \cdot 1$ & $32 \cdot 16$ & $29 \cdot 00$ & 1.55 & 26.05 \\
\hline
\end{tabular}

Table 1a. Analytical characteristics of the composite mixtures of colostrum fat

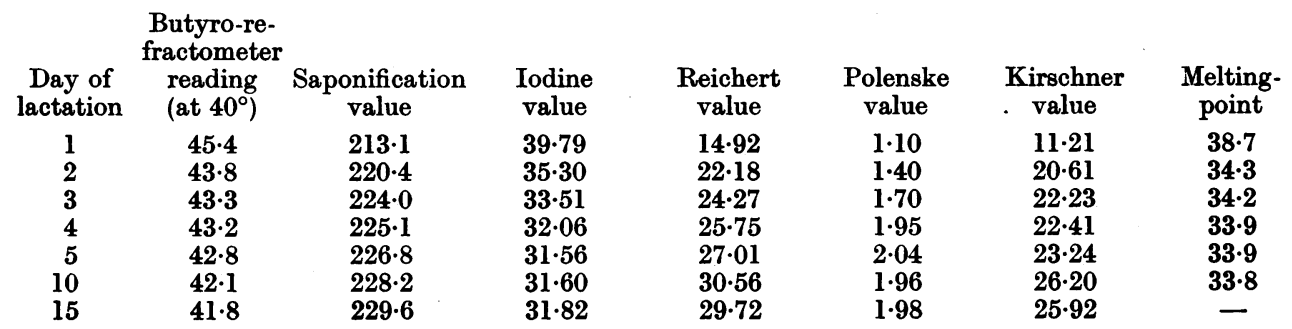


Table 2. Fractionation of the methyl esters prepared from $300 \mathrm{~g}$. of cow colostrum fat (first day of lactation)

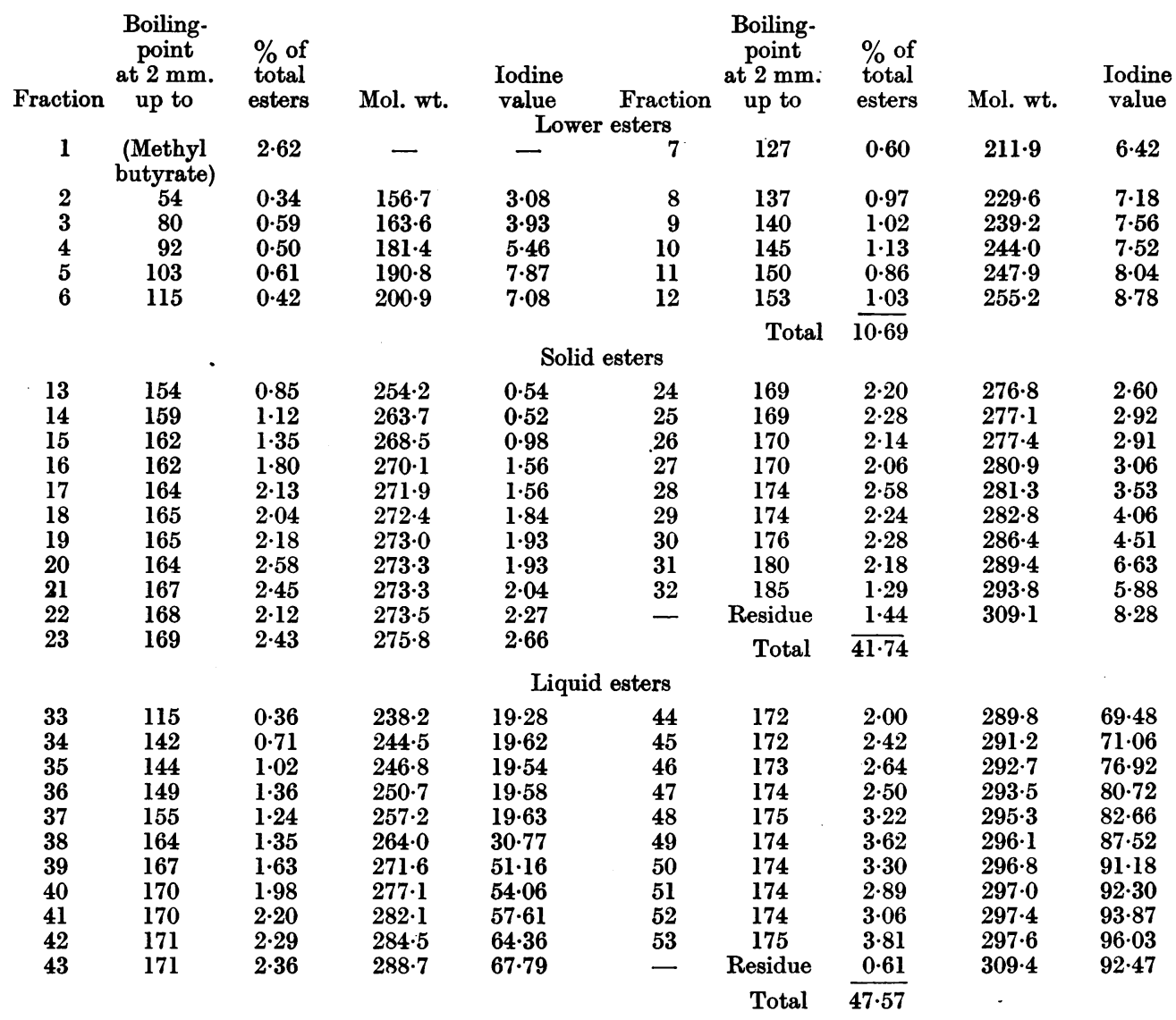

difference is in the very high content of palmitic acid (about $6 \%$ more) and low amount of linoleic acid $(6 \cdot 3 \%$ less $)$ in cow colostrum fat. Further, both colostral and mature human milk fat contain $\mathrm{C}_{22}$ and $\mathrm{C}_{24}$ unsaturated acids which are not found in either milk fat or colostrum fat secreted by the cow.

\section{DISCUSSION}

The analytical results indicate definite trends in the change in composition of the fat secreted by the cow as the period of lactation progresses. The change in composition of the fat secreted from the first day of lactation onwards is a gradual one. The component fatty acids are different from those of mature milk fat. In this respect the results confirm the findings of Baldwin \& Longenecker (1944a) that there is difference in the composition of mature and colostrum fat obtained from human milk. But the same authors (1944b) later reported that the fatty acid of cow colostrum fat is similar in composition to the typical butter fat as given by Hilditch \& Longenecker (1938). .Our findings do not agree with the observation made by these workers. The cow colostrum fat analyzed by them was obtained from a single animal, collected moreover during the first 4 days after parturition. We have analyzed composite samples of fat collected from six cows during the progress of lactation, and it may well be that if they had analyzed mature milk fat from the same cow the difference in composition might have been apparent. This change in composition of colostrum fat observed by us cannot be attributed to dietary effects since all the animals received the same diet during the period under observation.

At the start of lactation the cow probably uses her reserves for milk production, but whether these reserves are used specifically to synthesize fat or to furnish energy is unknown. Peterson, Palmer \& Eckles (1929) indicate that in the process of milk secretion a fat intermediate in character is first deposited in the glandular tissue and then modified to form milk fat itself. The short chain acids in 
Table 3. The component fatty acids and esters of cow colostrum fat (first day of lactation)

\begin{tabular}{|c|c|c|c|c|c|c|}
\hline \multirow[b]{3}{*}{ Acids } & & & & & \multicolumn{2}{|c|}{$\begin{array}{l}\text { Fatty acids } \\
\text { (excluding } \\
\text { unsaponi- } \\
\text { fiable) }\end{array}$} \\
\hline & \multicolumn{4}{|c|}{$\%$ as methyl esters } & \multirow{2}{*}{$\begin{array}{c}\% \\
\text { (wt.) }\end{array}$} & \multirow{2}{*}{$\underbrace{\%}_{(\mathrm{molar})}$} \\
\hline & Lower & Solid & Liquid & Total & & \\
\hline \multicolumn{7}{|l|}{ Saturated } \\
\hline $\mathrm{C}_{4}$ & $2 \cdot 38$ & - & 一 & $2 \cdot 38$ & $2 \cdot 2$ & $6 \cdot 3$ \\
\hline $\mathrm{C}_{6}$ & 0.02 & 一 & - & 0.02 & Trace & Trace \\
\hline $\mathrm{C}_{8}$ & 0.87 & 一 & 一 & $0 \cdot 87$ & 0.9 & $1 \cdot 5$ \\
\hline $\mathrm{C}_{10}$ & $1 \cdot 24$ & 一 & 一 & $1 \cdot 24$ & $1 \cdot 2$ & $1 \cdot 8$ \\
\hline $\mathrm{C}_{12}$ & $1 \cdot 38$ & - & $0 \cdot 04$ & $1 \cdot 42$ & $1 \cdot 4$ & $1 \cdot 8$ \\
\hline $\mathrm{C}_{14}$ & 3.52 & $0 \cdot 86$ & $5 \cdot 06$ & $9 \cdot 44$ & $9 \cdot 5$ & $10 \cdot 4$ \\
\hline $\mathrm{C}_{16}$ & 0.75 & $27 \cdot 89$ & $1 \cdot 79$ & $30 \cdot 43$ & $29 \cdot 7$ & $29 \cdot 0$ \\
\hline $\mathrm{C}_{18}$ & - & 10.90 & $2 \cdot 57$ & 13.47 & $13 \cdot 7$ & $12 \cdot 1$ \\
\hline $\mathrm{C}_{20}$ & - & $0 \cdot 61$ & - & $0 \cdot 61$ & $0 \cdot 6$ & 0.5 \\
\hline Total & $10 \cdot 16$ & $40 \cdot 26$ & $9 \cdot 46$ & $59 \cdot 88$ & $59 \cdot 2$ & $63 \cdot 4$ \\
\hline \multicolumn{7}{|c|}{ Unsaturated } \\
\hline $\mathrm{C}_{10}$ & 0.08 & 一 & - & 0.08 & $0 \cdot 1$ & $0 \cdot 1$ \\
\hline $\mathrm{C}_{12}$ & 0.06 & - & 一 & 0.06 & $0 \cdot 1$ & $0 \cdot 1$ \\
\hline $\mathrm{C}_{14}$ & 0.29 & - & 0.54 & $0 \cdot 83$ & 0.8 & $0 \cdot 9$ \\
\hline $\mathrm{C}_{16}$ & $0 \cdot 10$ & - & $3 \cdot 01$ & $3 \cdot 11$ & $3 \cdot 0$ & 3.0 \\
\hline $\mathrm{C}_{18}$ & 一 & $1 \cdot 48$ & $31 \cdot 98$ & $33 \cdot 46$ & $34 \cdot 1$ & $30 \cdot 3$ \\
\hline $\mathrm{C}_{18}$ & - & 一 & $1 \cdot 48$ & $1 \cdot 48$ & 1.5 & $1 \cdot 3$ \\
\hline $\mathrm{C}_{20-22}$ & - & - & $1 \cdot 10$ & $1 \cdot 10$ & $1 \cdot 2$ & 0.9 \\
\hline Total & 0.53 & $1 \cdot 48$ & $38 \cdot 11$ & $40 \cdot 12$ & $40 \cdot 8$ & $36 \cdot 6$ \\
\hline $\begin{array}{l}\text { Sum of } \\
\text { saturated } \\
\text { and un- } \\
\text { saturated } \\
\text { acids }\end{array}$ & $10 \cdot 69$ & $41 \cdot 74$ & $47 \cdot 57$ & $100 \cdot 00$ & $100 \cdot 0$ & $100 \cdot 0$ \\
\hline
\end{tabular}

milk fat are probably derived, as Hilditch first suggested, from the breakdown of some of the long chain acids in the blood fat. It is not clear whether the same process occurs at the initial stages of lactation. It may be that the lower acids are usec" in the synthesis of oleic acid, but during the first few days of lactation, when the gland is producing much less than the usual amount of fat, the smaller amount of synthesis taking place is able to proceed to its final stages, so that lower acids are almost wholly converted into oleic acid. It is in any case evident that, whatever the mechanism, the mammary gland takes some days to synthesize normal butter fat with the result that the first day's colostrum fat possesses a composition intermediate in character between body fat and milk fat.

\section{SUMMARY}

1. Samples of colostrum fat collected from six cows during the progress of lactation have been analyzed for chemical characteristics and the composite mixtures were subjected to fractionation in order to study the fatty acid composition.

2. The results indicate that there is a gradual decrease in the oleic acid, and an increase in the fatty acids of low molecular weight in the colostrum fat as lactation advances.

3. The colostrum fat differs in composition from normal butter fat.

Table 4. Summary of the component fatty acids of cow colostrum fat (expressed in weight and molar percentages)

\begin{tabular}{|c|c|c|c|c|c|c|c|c|c|c|c|c|}
\hline \multirow[b]{2}{*}{ Acids } & \multicolumn{6}{|c|}{$\begin{array}{l}\text { Weight percentages } \\
\text { Days in lactation }\end{array}$} & \multicolumn{6}{|c|}{$\begin{array}{l}\text { Molar percentage } \\
\text { Days in lactation }\end{array}$} \\
\hline & 1 & 2 & 3 & 4 & 5 & 10 & 1 & 2 & 3 & 4 & 5 & 10 \\
\hline $\begin{array}{l}\text { Butyric } \\
\text { Caproic } \\
\text { Caprylic } \\
\text { Capric } \\
\text { Lauric } \\
\text { Myristic } \\
\text { Palmitic } \\
\text { Stearic } \\
\text { Arachidic }\end{array}$ & $\begin{array}{r}2.2 \\
0.9 \\
1.2 \\
1.4 \\
9.5 \\
29 \cdot 7 \\
13 \cdot 7 \\
0.6 \\
\end{array}$ & $\begin{array}{r}2.4 \\
0.5 \\
1.2 \\
1.8 \\
1.8 \\
9.5 \\
32 \cdot 1 \\
12.5 \\
0.7 \\
\end{array}$ & $\begin{array}{r}2 \cdot 6 \\
0 \cdot 8 \\
1 \cdot 8 \\
2 \cdot 6 \\
2 \cdot 0 \\
10 \cdot 3 \\
30 \cdot 5 \\
12 \cdot 0 \\
0.9 \\
\end{array}$ & $\begin{array}{r}2 \cdot 8 \\
1 \cdot 5 \\
2 \cdot 0 \\
2 \cdot 3 \\
2 \cdot 7 \\
10 \cdot 7 \\
29 \cdot 0 \\
12 \cdot 6 \\
0 \cdot 8\end{array}$ & $\begin{array}{r}3 \cdot 6 \\
0 \cdot 6 \\
1 \cdot 8 \\
2 \cdot 0 \\
2 \cdot 6 \\
11 \cdot 1 \\
30 \cdot 3 \\
11 \cdot 6 \\
0.7\end{array}$ & \begin{tabular}{r|}
$3 \cdot 6$ \\
$0 \cdot 6$ \\
$1 \cdot 4$ \\
$1 \cdot 9$ \\
$2 \cdot 6$ \\
$10 \cdot 8$ \\
$29 \cdot 4$ \\
$12 \cdot 9$ \\
$1 \cdot 2$
\end{tabular} & $\begin{array}{r}6.3 \\
1.5 \\
1.8 \\
1 \cdot 8 \\
10 \cdot 4 \\
29 \cdot 0 \\
12 \cdot 1 \\
0.5\end{array}$ & $\begin{array}{r}6 \cdot 7 \\
1 \cdot 0 \\
2 \cdot 5 \\
2 \cdot 6 \\
2 \cdot 2 \\
10 \cdot 2 \\
30 \cdot 6 \\
10 \cdot 8 \\
0 \cdot 5\end{array}$ & $\begin{array}{r}7 \cdot 1 \\
1 \cdot 6 \\
3 \cdot 0 \\
3 \cdot 7 \\
2 \cdot 2 \\
10 \cdot 9 \\
28 \cdot 6 \\
10 \cdot 2 \\
0 \cdot 7\end{array}$ & $\begin{array}{r}7 \cdot 6 \\
3 \cdot 0 \\
3 \cdot 2 \\
3 \cdot 2 \\
3 \cdot 2 \\
11 \cdot 2 \\
26 \cdot 8 \\
10 \cdot 5 \\
0 \cdot 6\end{array}$ & $\begin{array}{r}9 \cdot 6 \\
1 \cdot 2 \\
3 \cdot 0 \\
2 \cdot 7 \\
3 \cdot 1 \\
11 \cdot 6 \\
28 \cdot 1 \\
9 \cdot 7 \\
0.5\end{array}$ & $\begin{array}{r}9 \cdot 9 \\
1 \cdot 3 \\
2 \cdot 3 \\
2 \cdot 5 \\
3 \cdot 1 \\
11 \cdot 3 \\
27 \cdot 3 \\
10 \cdot 8 \\
0 \cdot 9\end{array}$ \\
\hline Total & $59 \cdot 2$ & 62.5 & 63.5 & $64 \cdot 4$ & $64 \cdot 3$ & $64 \cdot 4$ & 63.4 & $67 \cdot 1$ & $68 \cdot 0$ & $69 \cdot 3$ & 69.5 & $\overline{69 \cdot 4}$ \\
\hline $\begin{array}{l}\text { Decenoic } \\
\text { Do-decenoic } \\
\text { Tetra-decenoic } \\
\text { Hexa-decenoic } \\
\text { Oleic } \\
\text { Linoleic } \\
\mathrm{C}_{20-22} \text { unsat. }\end{array}$ & $\begin{array}{r}0 \cdot 1 \\
0 \cdot 1 \\
0 \cdot 8 \\
3 \cdot 0 \\
34 \cdot 1 \\
1 \cdot 5 \\
1 \cdot 2 \\
\end{array}$ & $\begin{array}{r}0 \cdot 1 \\
0 \cdot 1 \\
0 \cdot 8 \\
3 \cdot 0 \\
31 \cdot 0 \\
1 \cdot 7 \\
0 \cdot 8 \\
\end{array}$ & $\begin{array}{r}0 \cdot 2 \\
0 \cdot 1 \\
0.9 \\
4 \cdot 7 \\
28 \cdot 2 \\
1 \cdot 6 \\
0 \cdot 8 \\
\end{array}$ & $\begin{array}{r}0 \cdot 2 \\
0 \cdot 2 \\
1 \cdot 1 \\
4 \cdot 7 \\
27 \cdot 5 \\
0 \cdot 8 \\
1 \cdot 1 \\
\end{array}$ & \begin{tabular}{r|}
$0 \cdot 2$ \\
$0 \cdot 3$ \\
$1 \cdot 2$ \\
$3 \cdot 3$ \\
$28 \cdot 8$ \\
$0 \cdot 5$ \\
$1 \cdot 4$ \\
\end{tabular} & $\begin{array}{r}0 \cdot 2 \\
0 \cdot 4 \\
0 \cdot 8 \\
3 \cdot 5 \\
29 \cdot 3 \\
0 \cdot 4 \\
1 \cdot 0 \\
\end{array}$ & $\begin{array}{r}0 \cdot 1 \\
0 \cdot 1 \\
0 \cdot 9 \\
3 \cdot 0 \\
30 \cdot 3 \\
1 \cdot 3 \\
0 \cdot 9 \\
\end{array}$ & $\begin{array}{r}0 \cdot 2 \\
0 \cdot 2 \\
0 \cdot 8 \\
2 \cdot 8 \\
26 \cdot 8 \\
1 \cdot 5 \\
0 \cdot 6 \\
\end{array}$ & $\begin{array}{r}0.3 \\
0 \cdot 2 \\
0 \cdot 9 \\
4 \cdot 4 \\
24 \cdot 0 \\
1 \cdot 5 \\
0 \cdot 7 \\
\end{array}$ & $\begin{array}{r}0 \cdot 3 \\
0 \cdot 3 \\
1 \cdot 1 \\
4 \cdot 4 \\
23 \cdot 1 \\
0 \cdot 7 \\
0 \cdot 8 \\
\end{array}$ & $\begin{array}{r}0 \cdot 3 \\
0 \cdot 3 \\
1 \cdot 3 \\
3 \cdot 0 \\
24 \cdot 2 \\
0 \cdot 4 \\
1 \cdot 0 \\
\end{array}$ & $\begin{array}{r}0.2 \\
0 \cdot 5 \\
0 \cdot 8 \\
3 \cdot 3 \\
24 \cdot 7 \\
0 \cdot 3 \\
0 \cdot 8 \\
\end{array}$ \\
\hline Total & 40.8 & $37 \cdot 5$ & 36.5 & $35 \cdot 6$ & $35 \cdot 7$ & $35 \cdot 6$ & $36 \cdot 6$ & 32.9 & 32.0 & $30 \cdot 7$ & 30.5 & $\overline{30.6}$ \\
\hline $\begin{array}{l}\text { Sum of acids up } \\
\text { to } C_{14}\end{array}$ & $16 \cdot 2$ & $18 \cdot 2$ & $21 \cdot 3$ & $23 \cdot 5$ & $23 \cdot 4$ & $22 \cdot 3$ & 22.9 & $26 \cdot 4$ & 29.9 & $33 \cdot 1$ & $33 \cdot 1$ & 31.9 \\
\hline
\end{tabular}




\section{REFERENCES}

Baldwin, A. R. \& Longenecker, H. E. (1944a). J. biol. Chem. 154, 255.

Baldwin, A. R. \& Longenecker, H. E. (1944b). J. biol. Chem. 155, 407.

Bosworth, A. W. \& Brown, J. B. (1933). J. biol. Chem. 103, 115.

Hilditch, T. P. \& Longenecker, H. E. (1938). J. biol. Chem. $122,497$.
Hilditch, T. P. \& Paul, H. (1936). Biochem. J. 30, 1905.

Nilson, H. W. (1891). Jber. Fortschr. Tierchem. 21, 142.

Peterson, W. H., Palmer, L. S. \& Eckles, C. M. (1929). Amer. J. Physiol. 90, 592.

Smith, J. A. B. \& Dastur, N. N. (1938). Biochem. J. 32, 1868.

Sommerfield, A. (1909). Handbuch der Milchkunde, p. 810. Wiesbaden.

\section{The Capsular Substance of Bacillus anthracis}

By W. E. HANBY AND H. N. RYDON, Unit for Bacterial Chemistry (Medical Research Council), The Lister Institute of Preventive Medicine, London, S.W. 1 ; formerly at the Middlesex Hospital, London, W. 1

(Received 24 January 1946)

Ivánovics and his colleagues (Ivánovics \& Erdös, 1937; Brückner \& Ivánovics, 1937; Ivánovics \& Brückner, 1937, 1938), following up the earlier work of others (Kramar, 1922; Tomcsik \& Bodon, 1934), isolated the capsular substance from capsulated strains of Bacillus anthracis and some related organisms in a state approaching purity; the material was shown to have the properties of a hapten, giving precipitates with anti-sera to capsulated strains of $B$. anthracis but failing to induce antibody formation or to confer protection against infection with B. anthracis when injected into animals. On hydrolysis, the capsular substance gave good yields of (1.-(-)-glutamic acid, enantiomorphous with the $i$ - $(+)$-acid normally encountered in proteins, and Ivánovics \& Brückner $(1937,1938)$ concluded that it was a polypeptide built up solely of $d$-(-)glutamic acid residues. The work described in the present paper had as its immediate object the elucidation of the detailed chemical structure of this material.

Our work has mostly been carried out with two capsulated strains of $B$. anthracis, viz. 'Vollum', a highly virulent strain originally obtained from Dr R. L. Vollum of the Sir William Dunn Institute of Pathology, Oxford, and 'HM', a non-sporing variant of low virulence obtained by Dr Bruce White, F.R.S., of the National Institute for Medical Research, Hampstead, by growing 'Vollum' in Sclavo serum (se日 Appendix).

\section{Isolation of crude capsular material}

After some preliminary trials the two following methods were found convenient for the isolation of the crude capsular substance:

(a) Cultures grown on agar are reaped, suspended in water and killed by autoclaving $\left(45 \mathrm{~min}\right.$. at $\left.115^{\circ}\right)$.
The autoclaved suspension is strongly acidified $(\mathrm{HCl})$ and treated with $3 \mathrm{vol}$. of ethanol; after removing bacterial debris by filtration or centrifugation, the crude capsular substance is precipitated from the filtrate by bringing to $\mathrm{pH}$ 8-9 with $\mathrm{NaOH}$. (This procedure is a development of a method, fully described in the Appendix, originally devised by Dr Bruce White.)

(b) Cultures grown in liquid media are autoclaved and centrifuged or filtered. The filtrate is treated with $10 \% \mathrm{CuSO}_{4}$ solution and the precipitated copper salt collected by centrifugation; the washed salt is dissolved in acid and decomposed with $\mathrm{H}_{2} \mathrm{~S}$. The filtrate from the CuS is adjusted to $\mathrm{pH} 8-9$ and precipitated with ethanol (3 vol.).

Crude materials so prepared from the Vollum and HM strains (and also from another strain, ' 99 ', of American origin) were serologically active, giving precipitates with the appropriate anti-serum at dilutions down to 1 in $10^{7}$. These crude preparations give extremely viscous solutions in water, and the best of them probably approximate very closely to the capsular substance as it occurs attached to the organism.

\section{Further purification of capsular substance}

Further purification of the capsular substance without extensive degradation is not easy. Dialysis in acid solution is not wholly satisfactory since. the molecular weight, calculated from the aminonitrogen content on the assumption that each molecule contains only one free amino-group, decreases considerably during the process, e.g. the amino-nitregen content of a crude preparation was doubled by keeping at $25^{\circ}$ for $48 \mathrm{hr}$. in solution at $\mathrm{pH}$ 2. The most satisfactory method of purification is by way of the silver salt, which is precipitated 